\title{
Research on the Application of Sustainable Concept in the Teaching of Environmental Art Design
}

\author{
Houping Deng \\ Nanchang University Gongqing College
}

Keywords: environmental art design, sustainable concept, teaching application

\begin{abstract}
The sustainable concept is the principle of sustainable authigenic based on Ecological Cybernetics, which covers nature, society, environment, economy, science and technology and other aspects, so as to achieve the goal of coordinated development for human living environment. Environmental art design includes landscape, architecture, city, ecology and other contents which is related to environment and design, even promotes sustainable development from the creation of ideal and pleasant living environment, has the development relationship of natural beauty and artistic beauty. Therefore, it is of great practical significance to explore the innovation of the teaching method for environmental art design with the concept of sustainable development.
\end{abstract}

Environmental art design combines city design, architectural landscape, ecological environment and many other design contents, its goal is to create an ideal living environment which is suitable for human settlement and social value. The sustainable concept is the important connotation of Scientific Outlook on Development, and it is also the basic principle to coordinate the development of nature and society. The integration of sustainable concept and environmental art design will solve the contradiction between human and society, economy, resource and environment from the perspective of satisfying ecology, to maintain the ecological balance of environmental art design.

\section{The relationship between the connotation of the sustainable concept and the environmental art}

The connotation of sustainable concept can be embodied in three aspects. One is to take the needs of human beings as the goal, two is to restrict human behavior, three is to promote the fair relationship between people and society and nature. For example, the sustainability of economic goal is to maintain the economic development, to improve the living standard of the people and to improve the quality of life. The sustainability of social goal is to follow the objective law of man in social change, to enhance the sense of responsibility for society, nature and children. The sustainability of resources goal is to scientifically and reasonably exploit and utilize the resource based on the sustainable development of resources, to promote the recycling and efficient utilization of ecological resources. For example, to introduce the clean energy, such as wind energy, solar energy, etc, to replace the consumption of petrochemical energy and the pollution of the environment. The relationship between environmental art design and sustainable concept is mainly concerned with the collaborative relationship between environmental art design and architecture, environment and landscape which is starting from the survival and life of human beings. Ecological housing should be green from the whole process of design, construction and use, so as to improve the good integration of people with architecture and environment. For example, Houses of Parliament designed by Forster, using high-tech ecosystem combined power generation system, to introduce architectural lighting into natural light, building energy utilizes the introduction of ventilation and heat recovery system, to reduce energy consumption, and to supply excess power to neighboring buildings. Adhering to the sustainable concept, to respect nature and save energy from protecting the ecological environment and building the goal of ecological urban living environment, will certainly become a new trend of environmental art design in the future. 


\section{Reforming the concept of environmental art education and adding the course of sustainable development and ecological view}

Environmental art design course teaching is mostly made up of professional art design courses, emphasizing the presentation of visual beauty and texture on the teaching concept, emphasizing the diversified pursuit of shapes and forms, ignoring the concerns of environment, nature, climate, energy and other conditions. This simplification meets the design concept of living or comfortableness, increases the waste of resources and aggravates the environmental pollution. The sustainability of environmental art design should be integrated sustainable development into the course of ecological concept, to let the students understand and apply the sustainable concept and reconstruct the environmental art design. If we add the course of ecological architecture design, we should highlight the learning of concept and knowledge of sustainable concept, and introduce more typical cases of ecological architecture at home and abroad, so as to enhance the sustainable development of environment. At the same time, in the course of the theory for environmental art design, need to integrate the concept of sustainable and ecological. For example, on the concept of tectonic environment, we should emphasize the embodiment of sustainable concept, such as building materials, landscape design, lighting design, business space and so on. We should adjust the teaching content from an ecological perspective, highlighting the utilization of natural resources, energy saving, materials and new technologies. For example, in the design of commercial lighting, need to integrate into the color temperature, light effects, connotation of lighting energy saving and environmental protection, can not only reduce the lighting standard, and weaken lighting effect to save energy, but from the application of modern technology to extend the life of light color, enhance light efficiency, reduce greenhouse gas emissions, to provide resource utilization. In addition, China's traditional residential design in the design of architectural appearance, environment, cultural heritage, pay more attention to the relationship between man and nature, these simple traditional residential building structure and environment, will also provide an important reference for the design of modern environmental art design. Therefore, we should excavate the content of sustainable concept and ecological concept from the traditional residential building environment, and apply it to the practice of modern environmental art design, so as to enhance the integration of environmental art design and national cultural characteristics.

\section{Taking sustainable concept as the core of teaching, widening the openness of environmental art design course}

The integration of environmental art and modern science and technology, taking the technology and art as the important baseline of environmental art design, to promote the development of social and economic. Therefore, the field of environmental art design has also been more integrated with regional and cultural characteristics, in order to realize the overall grasp and sustainable development of the environment. For example, in the design of the indoor environment, taking the 3R principle as the guide, to reduce energy consumption, to avoid the destruction of the environment, and to obtain the maximum environmental benefits. The course structure of environmental art design should establish the core idea of sustainable concept teaching and expand the comprehensiveness of environmental art design to the fields of science, art, technology and so on. In the learning of traditional environmental art courses, students should also add contents of environmental science, engineering technology and other disciplines, and optimize course structure from the linking of environmental knowledge and design technology, to let students understand the course of environmental art design should focus on the concept of ecological sustainable concept, and enhance the students' view of the environment, architecture and decoration. Of course, we can also analyze the classic environmental art design cases, fully explore and demonstrate the sustainable concept of environmental art design, and lay the foundation for students to participate in ecological design and highlight the ecological nature of environmental art design. The teaching of environmental art design should emphasize openness, and realize the comprehensiveness, integrity and openness of curriculum resources from environmental knowledge and design methods. In the 
traditional closed space, the emphasis of course teaching mainly focuses on the design of drawings, such as modeling and space. Although technology innovation and application are emphasized, the integrity of environmental art design is not taken into account, and the exploration of new materials and technologies is limited. We should set up a sustainable concept, adjust the rationalization structure of the curriculum for environmental art design, and widen the field of course knowledge. Such as in some environmental art design projects, we should encourage students to participate in social investigation, base environment analysis, building environment layout, architectural space planning, architectural environment form details, as well as the associated application of new technology, so that students can learn about sustainable ideas, enhance the consciousness of sustainable design. In addition, we should also be established between related environmental art and other university enterprise cooperation, provide more opportunities for students to practice, from the application of concept, environment art design method, new technology, new technology, new materials, enhance the design experience, to promote the students' comprehensive quality promotion.

\section{Reconstructing the knowledge structure of environmental art education with the concept of sustainable development and improving the comprehensive ability of design}

Environmental art design in the professional discipline structure is the line, including practical elements, cultural elements, economic elements and so on. Such as drawing knowledge, material knowledge, processing technology, and the use of various kinds of machinery, etc. All these are based on the actual demand of project design, and meet the requirements of environmental comfort for people from the sustainable development of the overall relationship of environment, technology and art. Cultural elements are mainly embodied in the visual aesthetic satisfaction of environmental art. Such as the integration with regional culture, the penetration of architectural history, humanistic culture, and the highlight of traditional factors and so on, have achieved inspiration for the design of architectural environment. Economic factors are mainly manifested in the combination of environmental art design and market and economic laws, and the economic and social benefits of design should be highlighted. For example, we can optimize the design ideas from the economic model, and make the rational selection of the environmental art design, construction, material, structure, form and so on. The sustainable concept of environmental art design should be embodied in the comprehensive design ability of the students. As to the environment art design performance, need to design, from the environment design, structure sketch model design, to enhance the environmental art design style, the design is clear on the design idea of expression and expression, students should be able to explain from the logic of language. Besides, environmental art design is not only reflected in professional knowledge and design ability, but also in conjunction with the surrounding environment. Especially under the concept of sustainability, we need to enhance the design innovation from multiple objectives of building environment design.

\section{Conclusions}

The sustainable concept has the characteristics of multidisciplinary and comprehensive, covering the fields of society, economy and ecology. The integration of sustainable concept in the teaching of environmental art design has also put forward higher requirements for teachers. In the teaching, teachers should integrate the relationship between good environment, art design knowledge and the concept of sustainable development, with the integrated design of lesson to deepen students' understanding of the concept of sustainable environmental art design. For example, introducing the case of traditional building renovation and protection, introducing a new energy-saving building case, so that students can reconstruct the relationship between many elements of the architectural environment from the sustainability of the design plan, and enhance the pertinence, professionalism and comprehensive level of teaching. 


\section{References}

[1] Linjun Yu. Discussion on the ecological concept in environmental art design [J]. Course education study, 2016 (35): 226.

[2] Yao Wang. Research on the sustainable development for the teaching of environmental art design [J]. Forest area teaching, 2016 (02): 88-89.

[3] Haoyang Wu. Ecological concept and its application of indoor environment art design [J]. modern occupation education, 2017 (19): 60.

[4] Discussion on project design in art design teaching [J]. Yi Zhang, Ruihua Xu. China university teaching. 2016 (04).

[5] Analysis on the application of visual symbols in the teaching of special education art design [J]. Min He, Kaihong Wang, Yu Wang. Art and technology. 2014 (07).

[6] Analysis on the role of tacit knowledge in the teaching of environmental art design. [J]. Lili Cao. Art 2012 (11).

[7] Construction of Chinese folk traditional handicraft culture in modern art design teaching [J]. Xianghong Ji. China Light Industry Education. 2011 (02). 